\title{
Diagnoses of Britain's Post-War Economic Problems: A Selective Survey
}

\section{B. S. Minhas}

Since the mid-1960s, particularly after the publication of the Brookings study in 1968, some important books, a large number of technical articles and a plethora of popular comments have been written on the state of the British economy, its record of growth and its prospects. This note brings together a selective summary of these diagnoses and findings, together with some of my own comments. Its scope is confined to a discussion of the objectives and instruments of economic policy in Britain, the structural consequences of the over-riding preoccupation with short-run management, the causes of low growth and productivity in comparison with other industrial countries and suggestions for improvement and change. My concern shall be mainly with important issues rather than with data and documentation.

In the past three decades, the dominant objective of economic policy in Britain has been the maintenance of as high a level of economic activity and employment as was compatible with the balance in international payments. Until very recently, price stability was not an object of policy in the sense that anything much was done to bring it about. Yet maintenance of employment and the balance in external payments each require separate policy instruments of adequate strength. If different aspects of aggregate activity such as price level and the rate of growth are also to be controlled, more instruments again are required.

Not only have British policy-makers been peculiarly obsessed with demand management but also they have been singularly narrow in their choice of instruments for the execution of this policy. The most conspicuous instrument of stabilisation policy, especially between 1949 and 1967, has been the frequent changes in fiscal policy. A simple model of the economy consisting of highly aggregated relationships, with almost no regard for the composition of aggregate supply, formed the basis of this policy. Once the future pattern of government expenditure was determined, a rate of tax consistent with immediate employment objectives was chosen. The resultant deficit of the public sector at the time of the budget provided a simple calculation (à la Cripps, Godley and Fetherston, 1974) of the balance of payments deficit when the aggregate public expenditure plan (separately calculated) remained unchanged in relation to projected GDP. Although different taxes and government outlays vary in their effects, the possible trade-offs between alternative changes in tax and expenditure policies do not appear to have been explicitly recognised in British budgetary practice.

In the general situation of inadequate reserves which has characterised post-war Britain, fluctuations in the balance of payments brought about by frequent alterations in budgetary policy have led to other compensatory policy changes. The latter did not normally, however, operate directly on the foreign balance. And on the whole they had a destabilising effect on the economy (Dow, Brookings), although this conclusion has been contested by Worswick (in Cairncross, ed. 1970). In a recent econometric study îrom the Department of Applied Economics, University of Cambridge, V. H. Woodward (in Barker, ed. 1976) argues that there is "a strong presumption that the past practice of attempting to stabilise employment in the short-run by fiscal policy largely aimed at controlling consumer demand was destabilising through its effects on the balance of payments. The implication for budgetary policy is that there should be greater stability in tax yield in relation to public expenditure than in the past".

Leaving aside the questions of definition and measurement involved in the concepts of 'stabilisation' and 'destabilisation', the claim has often been made that the British "stop-go" and the uncertainty created by it has adversely affected the growth of productive capacity. Mathew (in Cairncross, ed. 1970) is, however, more doubtful about the consequences of demand management policy:

"The conclusions do not dispose of the hypothesis that stop-go had a major influence in retarding capital accumulation; indeed, such a hypothesis is in principle hard to dispose of, because of the difficulty of saying what would have happened to business and labour attitudes if growth had been perfectly steady-a contingency never experienced. Equally, however, our conclusions do not give the hypothesis much support". 
Nevertheless Woodward and his colleagues (Barker, ed. 1976) are less agnostic and still maintain that the evidence supports the view that "stop-go" policies have had adverse effects on the underlying growth of productive capacity.

We have already noted the absence in British budgetary practice of the explicit recognition of trade-offs between alternative patterns of tax and expenditure policies. The public expenditure planning model has been essentially oriented towards aggregate demand and has failed to pay attention to the composition of demand. Because of the absence of any industrial disaggregation in the policy model, the supply side implications of planned public expenditure also could not be fully understood. The composition of public expenditure has changed greatly in the past quarter century and has produced a big structural shift in the allocation of labour force between the different sectors of the economy. This is shown in Table 1.

\section{Table 1-Growth of Employment}

(000)

1954-1963 1963-1973

1. Manufacturing

354

2. Other productive industries and services $\quad 780 \quad-90$

3. Government (excluding trading services)

4. Total Employment

Source: Barker, 1976: 368

Between 1954 and 1963, the sectors of the British economy producing "tradables" absorbed $1.13 \mathrm{mn}$. additional people; whereas between 1963 and 1973 the same sectors suffered a net loss of about half as many jobs. Over the same two periods, the additional jobs created in the "non-tradable" sector were respectively 33,000 and 929,000 . Barker and his colleagues have calculated that if the growth of government employment in non-tradables over the period 1963-73 had been no faster than during the earlier period (1954-63), there would probably have been no decline in manufacturing employment if appropriate tax and exchange rate policies had been pursued. "The underlying growth of the economy might have been about 0.4 per cent faster-a significant amount".

In view of the trends in population and labourforce growth, the lack of a labour reserve in agriculture and restraints on immigration, the
British authorities have become increasingly aware of the need to free labour resources for manufacturing. The introduction of Selective Employment Tax (SET) on private services in 1965 is evidence of this. But since public expenditure planning was based on a demand-oriented model of the economy, the contradictions between the objectives of SET and the increasing labour content of planned public expenditure were not detected. Although generous investment incentives were introduced (the effective tax rate on companies in 1963-73 was less than in 1954-63), the demand (and also the cash flow) was diverted away from industry. If manufacturing industry, so important for Britain's balance of payments, were distinguished as a separate sector in the Treasury's official model, the feedbacks between the demand for manufactures and their supply price and the consequence of increasing employment in the "non-tradable" sector on the growth of the economy might have been observed and allowed for.

At this stage a minor summing up is in order. The main instrument for employment stabilisation in the short run was frequent tax changes. Other instruments of policy were used only in subsidiary roles and none of these (certainly up to 1967) operated, with any significant force, directly on the foreign balance. Identification and use of specific short-run objectives and targets did not appear to have been explicitly attempted. Longrun structural aspects of the economy were either neglected or pursued in a manner in which different instrumeits of policy conflicted with each other and, probably contributed to fundamental difficulties which had adready become conspicuous by the time oil and commodity crises arrived.

A number of studies are available that have looked into the comparative experience of many Western industrial countries concerning shifts in labour-force use in the post-war period. The figures in Table 2 are taken from a recent and provocatively interesting British study.

The table illustrates three main points. Firstly the exhaustion of the labour-reserve in British agriculture compared especially with Germany and France. The latter were able to move 1.5 and $1.6 \mathrm{mn}$. workers respectively out of their agricultural sectors between 1961 and 1974, more than ten times the movement in the U.K. Secondly that although employment in the services sector has increased in all the major industrialised countries, the percentage change in the ratio of services to industrial employment (34 per cent in 13 years) was much the largest in the U.K. 
Thirdly, while industrial employment (comprising mining, manufacturing, construction, gas, electricity and water) expanded in the U.S., France and Japan, the number of industrial jobs in the U.K. fell by $1.5 \mathrm{mn}$.- a very significant amount.

Table 2-Numbers of Civilians Employed by Sector (000)

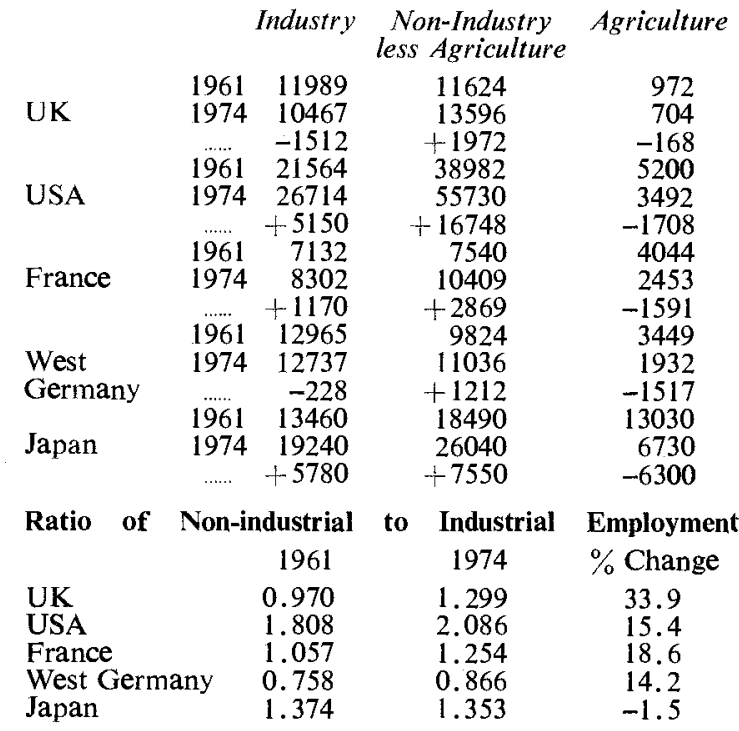

Source: Bacon and Eltis, 1976

It is in these comparatively pronounced shifts in the structure of employment and production that Bacon and Eltis have sought an explanation of the underlying deterioration in Britain's economic performance and the succession of crises in the 1960 s and 1970s.

"The explanation is that successive governments have allowed large numbers of workers to move out of industry and into various service [authors intend non-traded service] occupations, where they still consume and invest industrial products and produce none themselves; their needs have, therefore, been met at the expense of the balance of payments, the export surplus of manufactures, and investment in industry itself, so the deterioration in the balance of payments and Britain's rate of growth can be explained. Once the effect of taking away an increasing proportion of what workers produce is recognised, the great acceleration of wage inflation becomes readily explicable, and the need for tougher and tougher incomes policies (which other major economies have not needed) to attempt to contain inflation". (Bacon and Eltis, 1976; emphasis added).

These authors further argue that "the unemployment rate that is compatible with stable prices has risen drastically" and "an economy that will not accept this exceedingly high natural rate of unemployment will have extraordinary inflation or draconian incomes policies" like Britain.

It would appear from these arguments that the fact of too many non-producers (especially in local government sector), taking away resources from industrial investment and reducing the size of the industrial sector, is being made to explain all of Britain's past, present and future ills. The suggestion that the distribution of the national product governs the rate of growth is an old one. However, Denison's calculations (Brookings Study, 1968) for the period 1950 to 1962 did not show that Britain had an output composition which differed from what can be expected for an economy of the British income level. Bacon and Eltis' argument is based on 1961-74 data, but they have not done the comparable accountingfor-growth calculations of the kind that Denison did. Although none of the large Western countries has had a shift into public services as great as Britain's between 1961 and 1974, the shift in Sweden, Norway and Denmark has been even faster and these countries have not suffered from Britain's difficulties. The basic issue of low growth in Britain may not be related to the high level of public expenditure per se but, to some other factors which were operative in Britain but not in the US, Japan, Germany, France or the Scandinavian economies. We shall revert to these factors later.

Denison, in the study cited earlier, had concluded that "per person employed, the UK had less enterprise capital in the form of structures and equipment than any of the other countries except Italy". This was considered a contributory factor to lower levels of productivity in Britain. However, the empirical basis of Denison's capital estimates has been questioned. In Britain, the volume of industrial capital that survived the war, much of it built in the war, was high relatively to most other European countries. Since Denison disregarded survivals from the years before 1946, he understated Britain's stock of capital (especially that which is in the form of structures).

Another argument sometimes put forward to account for the slower rate of growth of productivity in Britain relates to the relatively low rate of industrial investment. Undoubtedly, the stock of manufacturing capital in Britain has grown more slowly than in the continental countries. Nevertheless between 1954 and 1969 capital in manufacturing in the UK rose 50 per cent faster than output. The significant feature of 
the situation is not that industrial "investment grew slowly but that output grew still more slowly". "The fact is", observed Cairncross (1970), "that the whole economy is permeated by the comparative sluggishness reflected in the statistics of productivity. All the figures seem to move up more slowly in Britain: productivity, production, consumption, exports, imports, investment and any other significant aggregates. It is the totality that needs explanation, not some individual feature of it". Cairncross further observed that "it is also difficult to treat a higher level of industrial investment as the key to higher productivity in Britain when the country is littered with expensive equipment of the most modern type that is simply not used at all: in the docks, in printing establishments, and in many other industries". He proposed that the question that needs to be asked is not, 'How could more investment be encouraged', but, 'Why is it that more investment is not worthwhile?'

Bacon and Eltis do address themselves to Cairncross' question and their answer is that profits are too low. Company profits (net of tax, capital consumption and stock appreciation) have fallen as a share of manufacturing output since 1964. In manufacturing industry, they were 17.5 per cent of value added in 1964, 7 per cent in 1970, 1971 and 1972 and only 3 per cent in 1973, out of which dividends had to be paid and finance for capital investment found. They argue that in Britain, instead of the saving-investment mechanism, the main determinants of profit margins have been government prices and incomes policies, trade unions and foreign competition. Although capital is becoming scarce, profit margins do not appear to be rising; and the scarce capital cannot be spread out amongst more workers by the adoption of labour-intensive techniques because despite growing unemployment, labour is not cheap, so there is no incentive for labour-intensive investment.

Another argument which is often advanced is that Britain's rate of growth of output has been low because labour constraints begin to operate early in the expansionary phase, especially in critical export sectors. The economy's full productive potential therefore does not get fully exploited. Although the main thrust of Bacon and Eltis' explanation of the failure of the economy to expand is that the industrial capacity has not been available to meet the country's need for goods during expansionary periods of the "stopgo" cycle, the lack of labour mobility-brought about by government policies-is also an important element in their argument. While industry lost
$1.5 \mathrm{mn}$. workers between 1961 and 1974, public sector employment expanded to absorb these workers. The expansion of employment with local authorities in this period was about 54 per cent-nearly $1 \mathrm{mn}$. workers extra. The workers taken on in recession were not available for industry in subsequent booms, so that shortage of labour helped to bring these booms to an end sooner than otherwise. In the following recession, the government created still more jobs in the public sector and these too became permanent. The attraction of white collar jobs, the education system, council housing rental arrangements, mortgages, etc. may explain why people wish to stay put. The expansion of public sector employment and the higher levels of unemployment benefits explains why people are able to do so.

Some technologists (Bowden, 1976) have argued that productivity in British industry is low because old, worn-out tools are used. Among other things, they pin the responsibility for this on the absence of a replacement cost principle in accounting practice (when prices have been rising) and on the British tax practice until November, 1974, of including any appreciation in the stock and work-in-progress in taxable company profits. This has in effect deprived industry of its ordinary working capital by treating it as if it were recurrent income. In consequence of this and relatively low rates of industrial investment, they contend, British industry is dying of broken tools. However, the evidence does not altogether support this hypothesis. In a detailed comparative study (Bacon and Eltis, 1974) it was found that the machine tools used in certain industries in Britain were no older than in the United States, and that the latter's lead in numerically controlled machine tools was only three years. Nevertheless, Britain had 50 per cent more men per machine and got one-third less output per machine. In another study (Central Policy Review Staff, 1975), it was found that British assembly lines with the same machines as European ones needed up to twice as many hours to assemble cars. If these results may be generalised-which is by no means completely certain-it appears that British industrial productivity is low not because the tools are old but because of over-manning and downright inefficiency.

The causes of this inefficiency have been attributed on the one hand to peculiarities of British industrial relations and on the other to inadequate training of business managers. It is claimed that the fragmented nature of unions, craft unions with shop floor bargaining and federation bargaining, leads to waste of time and effort. Although 
the number of hours lost per 1,000 hours of work in the UK may be no higher than in countries such as Germany and Sweden, the balkanised British unions cause localised and partial strikes which are far too disruptive of output: being almost comparable in their impact on industrial production and productivity to strategic bombing during World War II. Although this strikes an outsider as perhaps the dominant fact of British industry, there is little that one can suggest to disentangle Britain's complex labour relations closely related as they are to the class conflict entrenched in British society.

A number of other reasons are sometimes offered for Britain's low level of industrial productivity. These include a smaller proportion of engineers and applied scientists in industry and relatively poor remuneration of them vis a vis their remuneration in other comparable countries, and inadequacy and misdirection of $R$ and $D$ expenditure-too much in the aircraft industry, nuclear power and other defence related industries, relatively insignificant in other industries. There has been on the whole less controversy on these points, and the issues in question also seem to be more amenable to policy action by government and industry. Yet much more has been said about them by British politicians, industrialists and educators than has actually been done.

The single most important need in Britain today would seem to be for a medium and long-term policy framework for industrial expansion and structural change. The emphasis would have to shift to the supply structure of the economy rather than the usual obsession with aggregated demand management for short-term often purely political ends.

One particularly useful instrument for longer-run policy would be an indicative plan on the French or Japanese pattern, broken down by regions and policies to encourage competitive industries to relocate and expand in regions of declining employment, with adjustment assistance to industry and labour being seen as an integral part of an active industrial restructuring policy. The public expenditure plan (not necessarily involving smaller levels of public expenditure than hitherto), the supply side implications of which for resource allocation should be consistent with the objectives of industrial expansion and structural changes, should be integrated with the overall indicative plan. In the context of North Sea oil, the time would now seem right for an initiative towards a long-term policy framework in Britain.

North Sea oil should also afford Britain the opportunity to disentagle the instruments for the short-term control of domestic activity from those needed for correcting the balance of payments. It would be worthwhile to experiment with the idea of extensive retraining and rehousing (on the Swedish pattern) of labour in the downswing of the cycle and not to offer jobs to the industrial unemployed in occupations from which they would not want to come out to industry in the upswing. The French, and particularly the Germans, have enjoyed immense benefits conferred by the mobility of their labour forces made possible by the labour-reserve in agriculture and the presence of very mobile foreign workers.

Retraining of labour in times of cyclical unemployment should be combined with part-time work on public projects or local construction projects, preferably with short gestation periods and with minimal effects on the balance of payments. This approach to the alleviation of shortrun fluctuations in unemployment would be a good partial substitute for the usual unemployment benefits and too frequent changes in budgetary policy.

Nevertheless, the circumstances are bound to arise when it will be desirable to change tax incidence in relation to planned public expenditure. To take care of adverse movements in terms of trade of a more lasting nature, tax changes or public expenditure cuts would have to be made in such a way as to transfer resources into the balance of payments when it does not seem feasible to maintain levels of consumption by borrowing; and the long-term (indicative) plan should be fashioned in such a way as to provide the structural context for the stimulation and redirection of investment into exporting and other productive activities in the short-run.

\section{References}

Bacon, R. W. and Eltis, W. A., 1976, Britain's Economic Problem: Too Few Producers, Macmillan

Bacon, R. W. and Eltis, W. A., 1974, The Age of $U S$ and $U K$ Machinery, NEDO Monograph 3

Barker, T. S. (ed.), 1976, Economic Structure and Policy, Cambridge Studies in Applied Econometrics: 2, Chapman and Hall, London

Lord Bowden, 1976, 'Why Industry dies of Broken Tools', The Listener, 18 March

The Brookings Study, 1968. See Caves et al. below Budd, A.P., 1974 'Economic Policy and the Medium Term' in G. D. N. Worswick and F. T. Blackaby (eds.), The Medium Term Models of the British Economy, Heinemann, London 
Cairncross, Sir Alec (ed.), 1971, Britain's Economic Prospects Reconsidered, George Allen and Unwin, London

Caves, Richard E. et. al., 1968, Britain's Economic Prospects, George Allen and Unwin, London. Cited in text as 'Brookings, 1968'

Central Policy Review Staff 1975, The Future of the British Car Industry, HMSO, December
Cripps, T. F., Godley, W. A. H. and Fetherston, M., 1974, 'Public Expenditure and the Management of the Economy' in Public Expenditure, Inflation and the Balance of Payments, House of Commons Paper 328, HMSO, London

Dow, J. S., 1964, The Management of the British Economy, 1945-60, Cambridge University Press 